\title{
Ю.Я. ТИХОНЕНКО
}

Інститут ботаніки імені М.Г. Холодного НАН України вул. Терещенківська, 2, м. Київ, МСП-1, 01601, Україна mycol@botany.kiev.ua

\section{ГРИБИ РОДИНИ PUCCINIASTRACEAE В УКРАÏHI}

Ключові слова: Pucciniastraceae, Украӥна, видовий склад, поширення

Родина Pucciniastraceae - один із ключових таксонів для вивчення еволюції іржастих грибів. Ще від кінця XIX ст. вважалося, що вона займає базальне положення в еволюційному дереві порядку Pucciniales, оскільки теліальними господарями багатьох iï представників $є$ папороті, тоді як види інших родин іржастих грибів - здебільшого паразити покритонасінних. Однак наприкінці XX - на початку XXI ст. положення про еволюційну древність паразитів папоротеподібних піддали сумніву - спочатку за результатами кладистичного аналізу морфологічних ознак іржастих грибів (Hart, 1988), а згодом - і за даними молекулярної філогенетики (Sjamsuridzal et al., 1999; Maier et al., 2003; Wingfield et al., 2004; Aime, 2006). За останніми дослідженнями (Aime, 2006), біля основи кладограми порядку Pucciniales міститься родина Mikronegeriaceae, яка об'єднує 13 видів, поширених у тропіках та помірній зоні Південної півкулі, зокрема, види роду Mikronegeria Dietel в еціальній стадії паразитують на голонасінних із родин Araucariaceae, Cupressaceae i Podocarpaceae, а в теліальній - на видах родів Nothofagus Blume та Fuchsia L. і трапляються в Аргентині, Чилі та Новій Зеландії. Складною є історія вивчення і найбільшого в родині роду Pucciniastrum G.H. Otth. 3 нього то виділяли окремі роди (Calyptospora J.G. Kühn, Thecopsora Magnus та ін.), то знову об'єднували в один таксон. Сучасні дані підтверджують його поліфілетичність, але групи, на які пропонується розділити цей рід, не відповідають згаданим вище родам. 3 огляду на це ми вважаємо Calyptospora i Thecopsora синонімами роду Pucciniastrum.

Центри різноманітності й ендемізму родини Pucciniastraceae містяться у Східній Азії та Північній Америці. Більшість із відомих в Україні представників пукциніастрових мають дуже широкі голарктичні або євразійські ареали. Винятки становлять Melampsorella symphyti Bubák i 4 види роду Milesina Magnus (M. blechni (Syd. \& P. Syd.) Arthur ex Faull, M. dieteliana (Syd. \& P. Syd.) Magnus, M. krie-

(с) Ю.Я. ТИХОНЕНКО, 2013 geriana (Magnus) Magnus i M. murariae Syd. \& P. Syd.), ареали яких охоплюють лише Європу та Кавказ.

Загалом родина Pucciniastraceae представлена в Україні 25 видами семи родів. У Карпатських лісах виявлено 23 види цього таксона, тоді як у лісостеповій зоні України зареєстровано 11, у Поліссі - 4, а в степовій зоні -3 види, причому в смузі злакових степів і в Кримському Степу поки не знайдено жодного виду даної родини. Такий розподіл можна пояснити тим, що ареали природного поширення їхніх еціальних господарів (види родів Abies Mill., Larix Mill. i Picea A. Dietr.) в Україні обмежені Карпатами й окремими острівцевими місцезнаходженнями у північно-західній частині країни і на Поліссі. Зазначимо, що для двох із трьох знайдених у степовій зоні видів (Pucciniastrum agrimoniae (Dietel) Tranzschel i Pucciniastrum guttatum (J. Schröt.) Hyl., Jørst. \& Nannf.) еціальна стадія взагалі не відома. Однак, враховуючи здатність багатьох видів зимувати в стадії урединіоспор і відновлювати наступного року свій розвиток без участі еціального господаря, слід припустити існування й інших факторів, що обмежують розповсюдження представників цієї групи.

Іржасті гриби - паразити папоротей - представлені в Україні родами Hyalopsora Magnus (2 види), Milesina (7) та Uredinopsis Magnus (2). Для них характерна ще очевидніша приуроченість до регіону Карпат, аніж для родини загалом. Відомі лише два винятки: Hyalopsora polypodii (Pers.) Magnus, окрім Карпатських лісів, трапляється також у лісостеповій зоні та Гірському Криму, а Milesina murariae зареєстрована тільки в Гірському Криму. Види роду Hyalopsora, відзначені в Україні, розвиваються на Gymnocarpium dryopteris (L.) Newman i Cystopteris fragilis (L.) Bernh. Обидва роди живителів, за сучасною системою папоротеподібних (Christenhusz et al., 2011), належать до родини Cystopteridaceae, яка є сестринською групою щодо всіх інших еуполіпод-II. Зазначимо, що раніше ці роди відносили до різних родин (Athyriaceae та Dryopteridaceae). Таким чином, дані урединології підтверджують правильність виділення родини Cystopteridaceae.

ISSN 0372-4123. Ukr. Botan. Journ., 2013, vol. 70, № 3 
На відміну від розглянутих вище, види чотирьох інших поширених в Україні родів родини розвивають урединії і телії на покритонасінних рослинах: Melampsorella J. Schröt. - на представниках родин $\mathrm{Ca}$ ryophyllaceae та Boraginaceae; Melampsoridium Kleb. на видах Betulaceae; Naohidemyces S. Sato, Katsuya \& Y. Hirats. — на Ericaceae; Pucciniastrum - на Rosaceae, Rubiaceae, Onagraceae та Ericaceae.

Ряд видів родини Pucciniastraceae є рідкісними, відомими в Україні тільки з кількох локалітетів.

Hyalopsora aspidiotus (Peck) Magnus на Gymnocarpium dryopteris (L.) Newman - кілька знахідок лише 3 Карпат, остання з яких датована серпнем 1914 p. (Wróblewski, 1913, 1915, 1916; Namysłowski, 1911).

Melampsoridium carpini (Nees) Dietel на Carpinus betulus L. - три знахідки з Івано-Франківської і Тернопільської областей, остання з яких позначена вереснем 1913 р. (Бобяк, 1907; Wróblewski, 1913, 1914).

Melampsoridium hiratsukanum S. Ito ex Hirats. f. на Alnus incana (L.) Moench - адвентивний вид (природний ареал - Східна Азія та західна частина Північної і Південної Америки). За останні 15 років поширився у Західній та Центральній Європі. В УКраїні вперше відзначений у серпні 2010 р. (природний заповідник «Горгани») (Tykhonenko 2011).

Milesina blechni (Syd. \& P. Syd.) Arthur ex Faull на Blechnum spicant (L.) Roth - три знахідки з ІваноФранківської обл., остання з яких датована червнем 1914 p. (Wróblewski, 1916, 1922).

Milesina carpatorum Hyl., Jørst. \& Nannf. на Dryopteris filix-mas (L.) Schott - дві знахідки з Івано-Франківської обл. та Львова (1913 р.) (Wróblewski, 1913).

Milesina dieteliana (Syd. \& P. Syd.) Magnus на Polypodium vulgare L. - єдина знахідка з Івано-Франківської обл. (липень 1914 р.) (Wróblewski, 1916).

Milesina exigua (Faull) Faull ex Hirats.f. на Polystichum braunii (Spenner) Fée - єдина знахідка з ІваноФранківської обл. (липень 1914 р.) (Wróblewski, 1916).

Milesina kriegeriana (Magnus) Magnus на видах роду Dryopteris Adans. - кілька знахідок лише з ІваноФранківської обл., остання з яких - за червень 1916 p. (Wróblewski, 1916, 1922).

Milesina murariae Syd. \& P. Syd. на Asplenium rutamuraria L. - єдина знахідка з Гірського Криму (наведена без дати збору в монографії В.Г. Траншеля 1939 р.) (Траншель, 1939).

Milesina vogesiaca Syd. на видах роду Polystichum Roth - три знахідки з Івано-Франківської обл. та Львова, остання з яких - за травень 1917 р. (Wróblewski, 1916, 1922).
Pucciniastrum arcticum (Lagerh.) Tranzschel на $R u$ bus saxatilis L. - єдина знахідка з Сумської обл. (липень 2005 р.) (Тихоненко, Голубцова, 2007).

Pucciniastrum goeppertianum (J.G. Kühn) Kleb. на Vaccinium vitis-idaea L. - кілька знахідок лише 3 Івано-Франківської та Закарпатської областей, остання з яких датована липнем 1921 р. (Krupa, 1888; Namysłowski, 1909; Chmielewski, 1910; Wróblewski, 1913; Petrak, 1925).

Uredinopsis struthiopteridis F.C.M. Störmer на Matteuccia struthiopteris (L.) Tod. - дві знахідки з ІваноФранківської та Львівської областей, остання з них позначена квітнем 1917 p. (Wróblewski, 1916; Petrak, 1925).

Нижче наводимо ключі для визначення виявлених в Україні родів та видів родини Pucciniastraceae.

\section{Ключ для визначення родів}

1. Теліоспори розділені вертикальними або косими перетинками . . . . . . . . . . . . . . . 2

- Теліоспори одноклітинні . . . . . . . . . . . 6

2. Усі типи спор безбарвні. . . . . . . . . . . . 3

- Урединіоспори забарвлені, жовті до помаранчевих . . . . . . . . . . . . . . . . . 4

3. Урединіоспори на верхівці витягнуті в гострий шип. Теліоспори розсіяні в паренхімі . . . . . . . . . Uredinopsis - урединопсіс

- Урединіоспори на верхівці заокруглені. Теліоспори в клітинах епідермісу ..... Milesina - мілезина

4. Урединіоспори гладенькі або дрібнобородавчасті. Теліоспори безбарвні, в клітинах епідермісу. Урединії і телії на папоротеподібних . . . . . . . . . . . . . . . . . . ......... Hyalopsora - гіалопсора

- Урединіоспори шипуваті. Теліоспори бурі, в клітинах епідермісу або під епідермісом. Урединії і телії на покритонасінних. . . . . . . . . . . . . .5

5. Проросткові пори теліоспор у зовнішній оболонці кожної клітини . . . . . . . . . . . . . . . . Pucciniastrum - пукциніаструм

- Проросткові пори теліоспор у центрі кожної клітини . . . . . . . . . Naohidemyces - наохідеміцес

6. Теліоспори в клітинах епідермісу, майже безбарвні. Устьові клітини перидію урединіїв заокруглені .............Melampsorella - мелампсорела

- Теліоспори в щільному шарі під епідермісом, бурі. Устьові клітини перидію урединіїв витягнуті в шип ......... Melampsoridium - мелампсоридіум

\section{Ключ для визначення видів Hyalopsora}

1. Амфіспори 35-48 $\times 25-35$ мкм. Оболонка урединіоспор 1,0-1,5 мкмзавтовшки. На Gyтnосағріuт Newman .............. H. aspidiotus (рис. 1, a) 

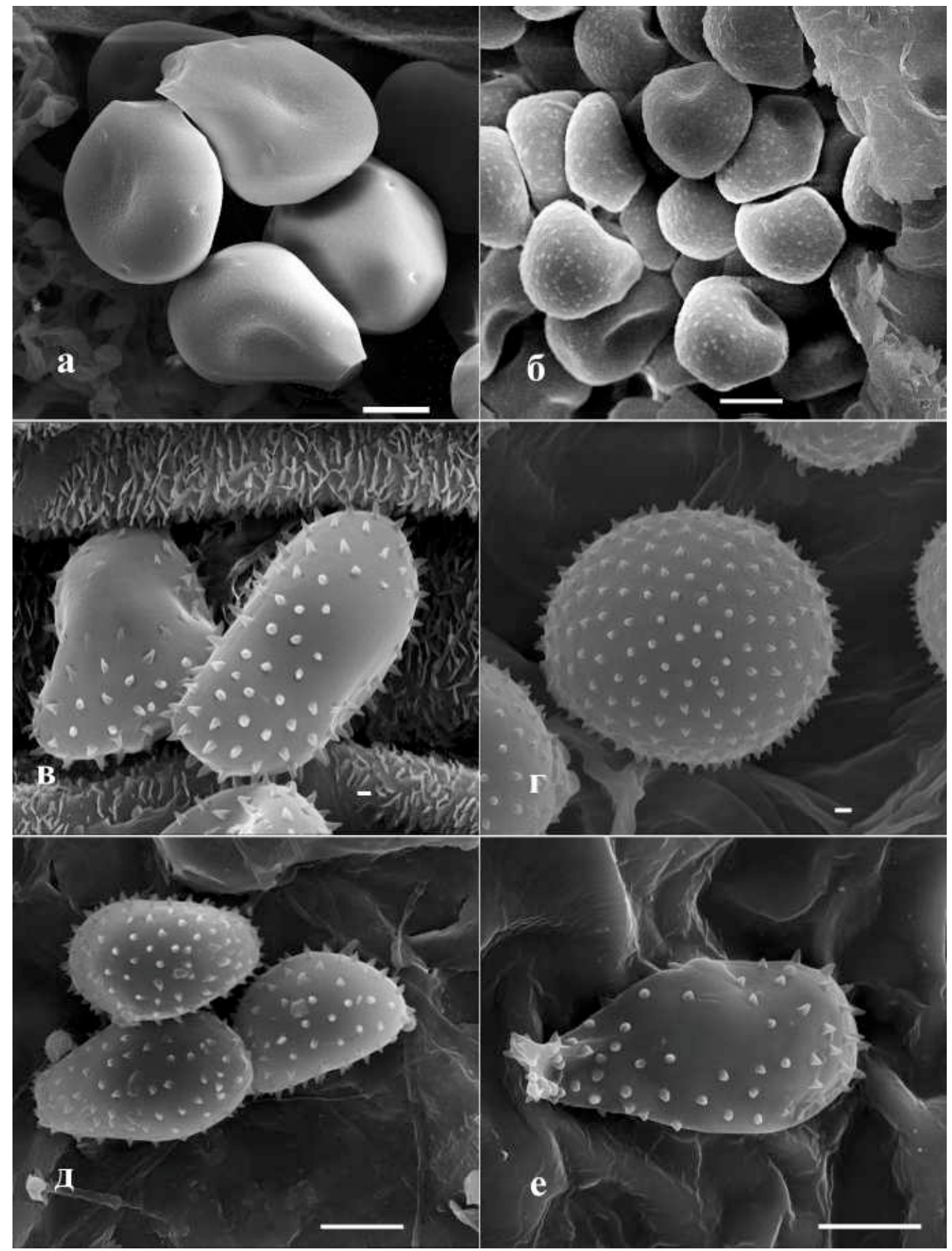

Рис. 1. a-Hyalopsora aspidiotus, амфіспори; 6 - Hyalopsora polypodii, урединіоспори; в - Melampsorella caryophyllacearum, урединіоспори; г - Melampsorella symphyti, урединіоспора; $\partial$ - Milesina blechni, урединіоспори; $e$ - Milesina dieteliana, урединіоспора. Розмір штриха: $a$, б, $\partial, e-10$ мкм; $6,2-1$ мкм

Fig. 1. $a-$ Hyalopsora aspidiotus, amphispores; $\sigma-$ Hyalopsora polypodii, urediniospores; $8-$ Melampsorella caryophyllacearum, urediniospores; 2 -Melampsorella symphyti, urediniospore; $\partial$-Milesina blechni, urediniospores; $e$-Milesina dieteliana, urediniospore. Scale bars: $a, \sigma, \partial, e-10 \mu \mathrm{m} ; \boldsymbol{B}, 2-1 \mu \mathrm{m}$ 
- Амфіспори дрібніші, 22-33 × 20-26 мкм. Оболонка урединіоспор до 1 мкм завтовшки. На Cystopteris Bernh................ polypodii (рис. 1, б)

\section{Ключ для визначення видів Melampsorella}

1. Стадії 0, I ..........................2

- Стадії II, III. . . . . . . . . . . . . . . . . ...3

2. На деформованих та скручених голках, які виростають на «відьминих мітлах». Еціоспори 20-30 × 12-23 мкм; клітини перидію завдовжки 2236 мкм................... caryophyllacearum

- Уражена хвоя і пагони живильної рослини не змінюють форми та розмірів. Еціоспори більші, 25-40 × 20-30 мкм; клітини перидію завдовжки 40-60 мкм . .................... M. symphyti

3. Урединіоспори 20-28 $\times 12-18$ мкм. На Caryo-

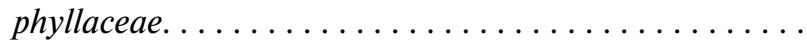
....M. caryophyllacearum (DC.) J. Schröt. (рис. 1, в)

- Урединіоспори більші, 22-36 × 18-26 мкм. На Boraginaceae ............ M. symphyti (рис. 1, г)

\section{Ключ для визначення видів Melampsoridium}

1. Оболонка урединіоспор по всій поверхні вкрита шипами. . . . . . . . . . . . . . . . M. hiratsukanum

- На апікальному кінці урединіоспор є вільна від шипів гладенька ділянка . . . . . . . . . . . . 2

2. Урединіоспори завдовжки 22-38 мкм. На видах Betula L. ........... M. betulinum (Pers.) Kleb.

- Урединіоспори завдовжки 17-30 мкм. На видах Carpinus L. . . . . . . . . . . . . . . . . . M. carpini

\section{Ключ для визначення видів Milesina}

1. Урединіоспори шипуваті . . . . . . . . . . . . . . 2

- Урединіоспори гладенькі . . . . . . . . . . .6 6

2. Ha Asplenium L. ................ murariae

- На інших папоротеподібних . . . . . . . . . . 3

3. Нa Blechnum L. ........ M. blechni (рис. 1, д)

- На інших папоротеподібних . . . . . . . . . 4

4. Ha Dryopteris Adans. . . . . . . . . . . . . . . . . . .5

- Ha Polypodium L........ M. dieteliana (рис. 1, e)

5. Урединіоспори 25-38 $\times 15-23$ мкм ........

......................... kriegeriana

- Урединіоспори дрібніші, 17-26 × 12-16 мкм

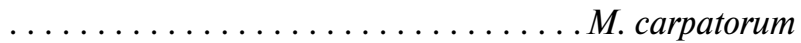

6. Урединіоспори 25-40 × 13-21 мкм ........ ........................... vogesiaca

- Урединіоспори дрібніші, 21-28 × 14-18 мкм ............................. еxigua
3 роду Naohidemyces в Україні відзначений один вид - Naohidemyces vacciniorum (J. Schröt.) Spooner (рис. 2,a)

\section{Ключ для визначення видів Pucciniastrum}

1. Теліоспори всередині клітин епідермісу господаря . . . . . . . . . . . . . . . . . . .

- Теліоспори між клітинами під епідермісом або в паренхімі . . . . . . . . . . . . . . . 4

2. Урединії розвиваються $\ldots \ldots \ldots \ldots \ldots \ldots$

- Урединії відсутні . . . . . . . . P. goeppertianum

3. Нa Rosaceae . . . . . . . . . . . . . . . . . . . . . . ........ P. areolatum (Fr.) G.H. Otth (рис. 2, в, г) - Нa Rubiaceae .......... P. guttatum (рис. 3, в, г)

4. Ha Rosaceae . . . . . . . . . . . . . . . . . . . . .5

5. Ha Agrimonia L. . . . . ... P. agrimoniae (рис. 2, б)

- Ha Rubus L. ..................P. arcticum

- на інших рослинах. ...............6

6. Ha Onagraceae . . . . . . . . . . . . . . . . . . 7

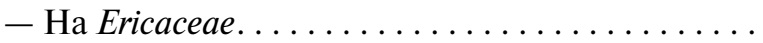
........... Pyrolae Dietel ex Arthur (рис. 3, $\partial, e$ )

7. Оболонка теліоспор завтовшки близько 1 мкм, здебільшого жовтувата, на верхівці не потовщена; на видах Circaea L.. . . . . . . . . . . . . . . . . . . . . . ......... P. circaeae (Schumach.) Speg. (рис. 2, д, е)

- Оболонка теліоспор завтовшки 1-2 мкм, темніша, на верхівці спори потовшена до 3-4 мкм; на видах Epilobium L. . . . . .................. .P. epilobii G.H. Otth (рис. 3, a, б)

\section{Ключ для визначення видів Uredinopsis}

1. Урединіоспори завдовжки 35-58 мкм (без шипа), 3 двома поздовжніми лініями видовжених бородавочок; амфіспори 25-38 × 18-23 мкм; на Matteuccia Tod. .................... struthiopteridis

- Урединіоспори дрібніші, 25-38 мкм завдовжки, гладенькі або з нерегулярно розміщеними бородавочками; амфіспори дрібніші, 20-29 × 12-16 мкм; на Phegopteris (K.B. Presl) Fée. . . . . . . . . . . .................. filicina (Niessl) Magnus

Видовий склад Pucciniastraceae в Україні вивчений досить повно, хоча в майбутньому не можна виключати появи на іiі території адвентивних видів зі Східної Азії та Північної Америки. При подальших дослідженнях особливу увагу слід звернути на рідкісні карпатські види, які вже тривалий час не реєструвалися українськими мікологами. 


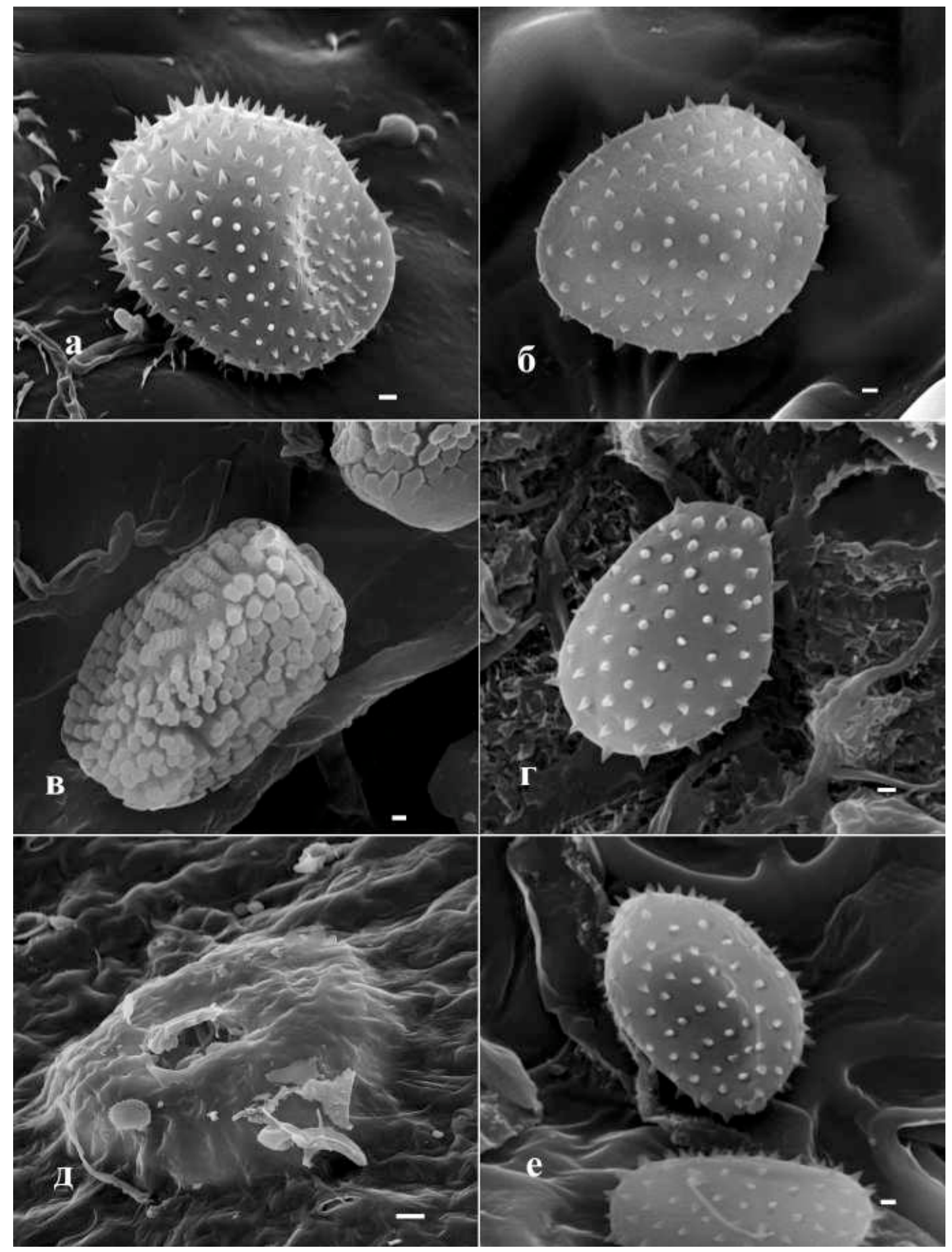

Рис. 2. a-Naohidemyces vacciniorum, урединіоспора; 6 - Pисciniastrum agrimoniae, урединіоспора; $в$ - Pисciniastrum areolatum, еціоспора; г - Pисciniastrum areolatum, урединіоспора; $\partial$ - Pисciniastrum circaeae, урединій; $e$ - Pисciniastrum circaeae, урединіоспора. Розмір штриха: $a, \sigma, \varepsilon, 2, e-1$ мкм; $\partial-10$ мкм

Fig. 2. $a-$ Naohidemyces vacciniorum, urediniospore; $\sigma-$ Pucciniastrum agrimoniae, urediniospore; $в-$ Pucciniastrum areolatum, aeciospore; 2 - Pucciniastrum areolatum, urediniospore; $\partial-$ Pucciniastrum circaeae, uredinium; e Pucciniastrum circaeae, urediniospore. Scale bars: $a, \sigma, b, 2, e-1 \mu \mathrm{m} ; \partial-10 \mu \mathrm{m}$ 


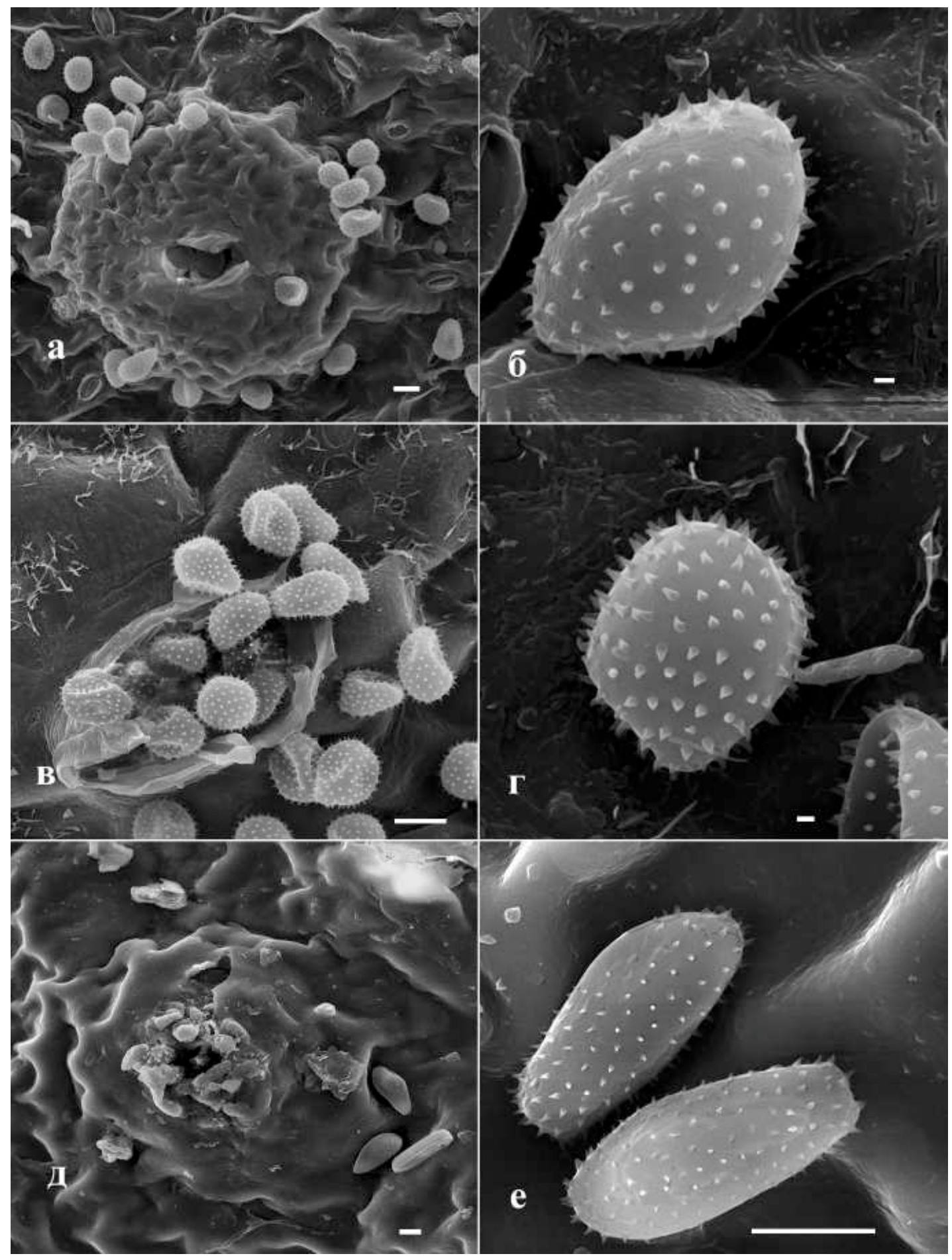

Рис. 3. a-Pucciniastrum epilobii, урединій; 6 - Pucciniastrum epilobii, урединіоспора; в - Pucciniastrum guttatum, устя урединію; 2 - Pucciniastrum guttatum, урединіоспора; $\partial-$ Pucciniastrum pyrolae, урединій; $e$ - Рисciniastrum pyrolae, урединіоспори. Розмір штриха: $a, b, \partial, e-10$ мкм; $6,2-1$ мкм

Fig. 3. a-Pucciniastrum epilobii, uredinium; $\sigma$ - Pucciniastrum epilobii, urediniospore; в - Pucciniastrum guttatum, ostiole of uredinium; $2-$ Pucciniastrum guttatum, urediniospore; $\partial-$ Pucciniastrum pyrolae, uredinium; $e-$ Pucciniastrum pyrolae, urediniospores. Scale bars: $a, b, \partial, e-10 \mu \mathrm{m} ; \sigma, 2-1 \mu \mathrm{m}$ 
Автор висловлює щиру подяку співробітникові Інституту ботаніки імені М.Г. Холодного НАН України 3.О. Паніній за допомогу в мікроскопічних дослідженнях.

\section{СПИСОК ЛІТЕРАТУРИ}

1. Бобяк Г. Причинки до мікольогії східної Галичини. Гриби околиці Бережан // Збірн. математично-природописно-лікарської секції Наук. т-ва ім. Шевченка. 1907. - 11. - C. 1-41.

2. Тихоненко Ю.Я., Голубцова Ю.І. Pисciniastrum arcticum (Lageh.) Tranzschel - новий для України вид іржастих грибів // Укр. ботан. журн. - 2007. - 64, № 2. - С. 266-269.

3. Траншель В.Г. Обзор ржавчинных грибов СССР. - М.: Изд. АН СССР, 1939. - 426 с.

4. Aime M.C. Toward resolving family-level relationships in rust fungi (Uredinales) // Mycoscience. - 2006. - 47. - P. 112122.

5. Chmielewski Z. Zapiski grzyboznawcze z Czarnej Hory // Kosmos. - 1910. - 35(7/9). - S. 804-813.

6. Hart J.A. Rust fungi and host plant coevolution: do primitive hosts harbor primitive parasites? // Cladistics. - 1988. - 4. P. 339-366.

7. Krupa J. Zapiski mykologiczne z okolic Lwowa i z Podtatrza // Sprawozdanie Komisyji Fizyograficzney. Ed. Akademja Umiejętności. - 1888. - 22(2). - S. 12-47.

8. Maier W., Begerow D., Weiß M., Oberwinkler F. Phylogeny of the rust fungi: an approach using nuclear large subunit ribosomal DNA sequences // Can. J. Bot. - 2003. - 81. - P. 1223.

9. Namysłowski B. Zapiski grzyboznawcze z Krakowa, Gorlic i Czarney Hory // Sprawozdanie Komisji Fizjograficzney Polskiej Akademii Umiejętności. - 1909. - 43(2). - S. 3-30.

10. Namystowski B. Prodromus Uredinearum Galiciae et Bukowinae // Sprawozdanie Komisji Fizjograficzney Polskiej Akademii Umiejętności. - 1911. - 45(3). - S. 65-146.

11. Petrak F. Beiträge zur Pilzflora Südost-Galiziens und der Zentralkarpathen // Hedwigia. - 1925. - 65(6) . - S. 179-330.

12. Sjamsuridzal W., Nishida H., Ogawa H., Kakishima M., Sugiyama $J$. Phylogenetic positions of rust fungi parasitic on ferns: evidence from 18S rDNA sequence analysis // Mycoscience. - 1999. - 40. - P. 21-27.

13. Tykhonenko Yu.Ya. First record of the rust fungus Melampsoridium hiratsukanum $\mathrm{S}$. Ito in Ukraine // Укр. ботан. журн. 2011. - 68, № 1. - C. 129-132.

14. Wingfield B.D., Ericson L., Szaro T., Burdon J.J. Phylogenetic patterns in the Uredinales // Australasian Plant Pathology. 2004. - 33. - P. 327-335.

15. Wróblewski A. Przyczynek do znajomości grzybów Pokucia. I // Sprawozdanie Komisji Fizjograficzney Polskiej Akademii Umiejętności. - 1913. - 47(2). - S. 147-178.

16. Wróblewski A. Przyczynek do znajomości grzybów Podola. I // Sprawozdanie Komisji Fizjograficzney Polskiej Akademii Umiejętności. - 1914. - 48(2). - S. 3-15.

17. Wróblewski A. Spis grzybów zebranych na Ziemiach Polskich przez Feliksa Berdaua i Aleksandra Zalewskiego oraz wybra- nych z zielników Komisyi Fizyograficznej Akademii Umiejętności przez Prof. M. Raciborskiego // Sprawozdanie Komisji Fizjograficzney Polskiej Akademii Umiejętności. 1915. - 49. - S. 92-125.

18. Wróblewski A. Drugi przyczynek do znajomości grzybów Pokucia i Karpat Pokuckich // Sprawozdanie Komisji Fizjograficzney Polskiej Akademii Umiejętności. - 1916. - 50. S. 82-154.

19. Wróblewski A. Wykaz grzybów zebranych w latach 1913-1918 z Tatr, Pienin, Beskidów Wschodnich, Podkarpacia, Podola, Roztocza i innych miejscowości. I. Phycomycetes, Ustilaginaceae, Uredinales i Basidiomycetes // Sprawozdanie Komisji Fizjograficzney Polskiej Akademii Umiejętności. - 1922. 55/56. - S. $1-50$.

Рекомендує до друку

Надійшла 15.02.2013 p.

I.О. Дудка

\section{Ю.Я. Тихоненко}

Институт ботаники имени Н.Г. Холодного НАН Украины, г. Киев

\section{ГРИБЫ СЕМЕЙСТВА PUCCINIASTRACEAE В УКРАИНЕ}

Семейство Pucciniastraceae представлено в Украине 25 видами 7 родов (Pucciniastrum G.H. Otth -8 видов, Milesina Magnus - 7, Melampsoridium Kleb. - 3, Hyalopsora Magnus, Melampsorella J. Schröt. и Uredinopsis Magnus - по 2 вида, Naohidemyces S. Sato, Katsuya \& Y. Hirats. - 1 вид). В Украинских Карпатах отмечено 23 вида этого таксона, тогда как в лесостепной зоне Украины зарегистрировано 11, в Полесье - 4, а в степной зоне -3 вида. Приведены ключи для определения встречающихся в Украине родов и видов семейства Pисciniastraceae. Работа иллюстрирована 18 микрофотографиями.

Ключ че в е е сло в а: Pucciniastraceae, Украина, видовой состав, распространение.

\section{Yu.Ya. Tykhonenko}

M.G. Kholodny Institute of Botany,

National Academy of Sciences of Ukraine, Kyiv

\section{FUNGI OF THE FAMILY PUCCINIASTRACEAE IN UKRAINE}

The family Pucciniastraceae is represented in Ukraine by 25 species of 7 genera (Pucciniastrum G.H. Otth -8 species, Milesina Magnus - 7 species, Melampsoridium Kleb. -3 species, Hyalopsora Magnus, Melampsorella J. Schröt. and Uredinopsis Magnus 2 species each, Naohidemyces S. Sato, Katsuya \& Y. Hirats. - 1 species). In the Ukrainian Carpathians, 23 species of this family are reported, while in the Forest-Steppe zone of Ukraine - 11 species, Polissia -4 , and in the Steppe zone -3 species. Keys for identification of Ukrainian genera and species of Pucciniastraceae are presented. The article is illustrated with 18 microphotographs.

Ke y words: Pucciniastraceae, Ukraine, species, distribution. 